\title{
PENGARUH STRUKTUR ORGANISASI TERHADAP KEEFEKTIFAN ORGANISASI DI SEKRETARIAT DAERAH (SETDA) KABUPATEN TASIKMALAYA
}

\author{
1 Adi Kurnia \\ 1 STIA YPPT Priatim Tasikmalaya \\ email:adi11021959@gmail.com
}

\begin{abstract}
Regional Secretariat (Regional Secretariat) both institutionally and functionally occupies a strategic position as the center of organizational and management activities in the region. Personally the employees are a group of individuals who possess specialists and competencies that are bound by the structure in carrying out such complex tasks and functions; The dynamics of organizational development and government management shows the level of development is increasingly oriented towards the use of information technology. The problem of this research starts from the effectiveness of the Regional Secretariat organization in carrying out its function as a staff organization. The results of data analysis, Organizational Structure has a correlation (r) of 0.842 to Organizational Effectiveness. The Effect of Organizational Structure on Organizational Effectiveness is 70.8\%. F Test Results, simultaneously there is a positive and significant effect between Organizational Structure on Organizational Effectiveness in the Regional Secretariat of Tasikmalaya Regency. Partially, the Complexity Dimension (X1), Formalization Dimension (X2) and Centralization Dimension (X3) have a positive but not significant effect on Organizational Effectiveness (Y) in the Regional Secretariat of Tasikmalaya Regency. The conclusion of this study is that organizational structure simultaneously has a positive and significant influence on Organizational Effectiveness and Partially, Complexity X1, Formalization X2, Centralization X3 has a positive but not significant effect on Organizational Effectiveness in the Regional Secretariat of Tasikmalaya Regency
\end{abstract}

Keywords: organizational structure, organizational effectiveness, competence

\begin{abstract}
Abstrak
Setda (Sekretariat Daerah) baik secara kelembagaan maupun secara fungsional menempati kedudukan setrategis sebagai pusat dari kegiatan organisasi dan menajemen di daerah. Secara personal para pegawai merupakan sekumpulan individu yang memliki spesialis dan kompetensi yang terikat dengan struktur dalam menjalankan tugas pokok dan fungsinya yang demikian kompleks; Dinamika perkembangan organisasi dan manajemen pemerintahan
\end{abstract}


menunjukan tingkat perkembangan semakin pesat berorientasi kepada pemanfaatan teknologi informasi. Permasalah penelitian ini bertolak dari belum efektifnya organisasi Setda di dalam menjalankan fungsinya sebagai organisasi staff. Hasil analisis data, Struktur Organisasi memiliki korelasi (r) sebesar 0,842 terhadap Keefektifan Organisasi. Pengaruh Struktur Organisasi terhadap Keefektifan Organisasi sebesar 70,8 \%. Hasil Uji F, secara simultan terdapat pengaruh positif dan signifikan antara Struktur Organisasi terhadap Keefektifan Organisasi di Sekretariat Daerah Kabupaten Tasikmalaya . Secara parsial, Dimensi Kompleksitas (X1), Dimensi Formalisasi (X2) dan Dimensi Sentralisasi (X3) berpengaruh positif tetapi tidak signifikan terhadap Keefektifan Organisasi (Y) di Sekretariat Daerah Kabupaten Tasikmalaya. Simpulan penelitian ini bahwa Struktur Organisasi secara simultan memiliki pengaruh positif dan signifikan terhadap Keefektifan Organisasi dan secara parsial, Kompleksitas X1, Formalisasi X2, Sentralisasi X3 berpengaruh positif tetapi tidak signifikan terhadap Keefektifan Organisasi di Setda Kabupaten Tasikmalaya.

\section{Kata kunci: $\quad$ struktur organisasi, keefektivan organisasi, kompetensi}

\section{A. Pendahuluan (Introduction)}

Organisasi publik pada umumnya menggunakan desain dan struktur organisasi berdasarkan prinsip-prinsip birokrasi (Weberian) yang dikritisi banyak pihak, termasuk praktisi dan akademisi. Kritik terhadap birokrasi, selain menyangkut aspek teoritis yang teramat impersonal (kaku) dan dari aspek perilaku birokrasi yang tidak produktif serta korup. Fenomena tersebut tidak dapat dilepaskan dari birokrasi pemerintah saat ini, yang menunjukan dua sisi perbedaan secara diametral. Pada sisi lain memperlihatkan suatu prestasi melalui pemanfaatan teknologi informasi sebagai daya dukung pelayanan birokrasi kepada masyarakat, pada sisi lain masih nampak perilaku tidak produktif yang disebabkan korupsi.

Dalam kaitan dengan struktur organisasi administrasi publik, (Keban ,2014) mengangkat sejumlah pertanyan mendasar, diantaranya, pertama, apakah tepat differensi vertikal dan differensi horisontal telah sesuai dengan besarnya beban kerja dan kompleksitas pekerjaan yang harus ditangani, kedua, apakah pihak yang mengerjakan pekerjaan tersebut mampu atau memiliki kompetensi yang memadai dalam mengerjakannya. Dan ketiga, apakah ada keseimbangan antara otoritas dalam mengerjakan suatu tugas, dengan kemampuan menjalankan tugas tersebut ? Sejumlah pertanyaan mendasar tersebut sayangnya sebagaimana dikatakan (Keban 2014) jarang dilakukan penelitian terkait dengan hal tersebut, sehingga tidak diketahui apakah disain organisasi publik sudah tepat atau belum, aspek-aspek mana yang masih perlu diperbaiki, dan apa dampaknya bila tidak segera diperbaiki. 
Penelitian ini bertolak dari latar belakang ketertarikan dari aspek teoritis dimana struktur organisasi terkait secara langsung dengan pengelolaan organisasi dimana individu dan kelompok mengambil peran melalui sinergi diantara anggotanya yang terikat oleh suatu sistem dan mekanisme yang harus dilalui dan dilaksanakan secara konsisten sehingga organisasi berjalan sesuai dengan struktur yang telah ditentukan. Aspek kedua latar belakang penelitian ini, sebagaimana kekhawatiran (Keban 2014) bahwa penelitian terkait dengan struktur organisasi relatif jarang dilakukan sehingga infomasi penting yang bertalian dengan disain dan struktur organisasi relatif jarang diketahui karena sedikitnya berbagai hasil penelitian yang dapat diperoleh dari publikasi jurnal ilmiah relatif sedikit pula. Terdorong oleh berbagai hal terkait dengan persoalan relatif jarangnya aktivitas terhadap penelitian terkait dengan disain dan struktur organisasi, penelitian ini dilakukan dalam rangka memperkaya berbagai kajian hasil penelitian struktur organisasi.

Penelitian ini mengambil lokasi di Sekretariat Daerah (SETDA) Kabupaten Tasikmalaya. Sekretariat merupakan organisasi staff yang berfungsi terhadap daya dukung secara operasional pada organisasi lini, yakni Satuan Kerja Perangkat Daerah (SKPD) atau dinas-dinas daerah dalam menyelenggarakan kegiatan otonomi daerah. Daya dukung Sekretariat Daerah merujuk kepada kegiatan organisasi dan manajemen yang mewujudkan berbagai jenis pelayanan dan hal lain yang sifatnya membantu kegiatan operasional dinas-dinas daerah tersebut.

Secara struktural, organisasi Sekretariat Daerah dibawah unsur pimpinan Sekretaris Daerah (SEKDA) dibantu oleh para Asisten yang masing-masing asisten mengkoordinasikan kegiatan di bawah tanggungjawab Bagian. Struktur organisasi Setda mencerminkan kompleksitas organisasi, baik secara vertikal maupun horizontal yang menunjukan diferensiasi tugas yang sangat kompleks pula. Diferensiasi tugas menunjukan dinamika perkembangan organisasi di dalam kaitannya dengan tuntutan dan perkembangan jaman, termasuk menyangkut pula dinamika kerja yang berkaitan dengan pola kerja dan orientasi kerja yang konsekuensinya diikuti oleh kompetensi pegawai yang bertanggungjawab dalam menjalankan tugas pokok dan fungsinya.

Sekretariat Daerah sebagai suatu institusi menampilkan pola hubungan diantara unit atau satuan-satuan organisasi yang di dalamnya terdapat unsur pimpinan atau pengurus, serta tugas dan wewenangnya masing-masing dalam melaksanakan pembangunan kelembagaan organisasi dan tujuan organisasi yang melibatkan semua komponen secara terpadu. Permasalahannya, sebagaimana dikatakan (Keban 2014) adalah, apakah tepat diferensiasi vertikal (jarak dari unit yang paling bawah ke unit paling atas) dan diferensi horizontal (jumlah dan unit ke samping) telah sesuai dengan besarnya beban kerja dan kompleksitas pekerjaan yang ditangani? apakah pihak yang mengerjakan pekerjaan tersebut mampu atau memiliki kompetensi yang memadai dalam mengerjakannya? apakah ada 
kesimbangan antara otoritas dalam mengerjakan suatu tugas dengan kemampuan dalam tugas tersebut?

Sejumlah pertanyaan tersebut membutuhkan jawaban melalui penelitian. Jawaban atas sejumlah pertanyaan mendasar tersebut diharapkan dapat menjelaskan di dalam kaitannya dengan variabel terikat, kefektifan organisasi, Keefektifan organisasi dimaksud terkait dengan tingkat efektifitas tugas dan fungsi dari Sekreatriat Daerah sebagaimana ditentukan dalam peraturan perundang-undangan di dalam menjalankan tugas pokok dan fungsinya.

Sejumlah pertanyaan tersebut menjadi latar belakang penelitian untuk suatu alasan yang logis mengapa kajian terkait dengan struktur organisasi demikian penting dan perlu diteliti. Struktur organisasi berdampak kepada kefektifan organisasi, maka selain mengkaji berbagai aspek atau dimensi yang mendasari struktur organisasi seperti kompleksitas, formalisasi dan sentralisasi, tentu saja penelitian ini dikaitkan secara korelatif pengaruhnya dengan kefektifan organisasi itu sendiri yang diposisikan sebagai variabel terikat. Atas dasar latar belakang di atas, maka penelitian ini akan dilakukan dengan mengambil lokasi di Sekretariat Daerah Kabupaten Tasikmalaya. Terdapat sejumlah alasan mengapa penulis menempatkan lokasi penelitian di Sekretariat Kabupaten Tasikmalaya? Pertama, secara kelembagaan dan fungsinya, SETDA menempati kedudukan setrategis sebagai pusat dari kegiatan organisasi dan menajemen di daerah, secara personal para pegawai di lingkungan SETDA merupakan sekumpulan individu yang memliki spesialis dan kompetensi yang terikat dengan struktur dalam menjalankan tugas pokok dan fungsinya yang demikian kompleks. Kedua, dinamika perkembangan organisasi dan manajemen Pemerintah menunjukan tingkat perkembangan semakin pesat yang berorientasi kepada teknologi informasi, perkembangan ini harus sejalan dengan aktivitas penelitian para akademisi dalam mengembangkan paradigma administrasi publik yang terus dikembangkan melalui media penelitian itu sendiri. Ketiga, penelitian terkait dengan struktur organisasi relatif jarang diminati dan dilaksanakan. Setidaknya penelitian ini dapat merangsang minat terhadap kajian organisasi, khususnya struktur organisasi yang sangat penting dan berpengaruh terhadap keefektifan organisasi dalam penyelenggaran otonomi daerah.

Terdapat tiga dimensi penting struktur organisasi. Mengikuti pendapat (Robbins 1994) terdapat tiga komponen penting dalam struktur organisasi. Pertama, kompleksitas. Kompleksitas merujuk pada tingkat diferensiasi yang terdapat dalam suatu organisasi, baik vertikal, horizontal, maupun spasial. Perubahan pada salah satu diferensiasi tersebut dapat menyebabkan perubahan secara keseluruhan diferensiasi. Sebab terjadinya diferensiasi horizontal terkait dengan dinamika perkembangan organisasi melalui tahap-tahap pertumbuhannya. (Kusdi, 2009, hlm. 169), mengatakan bahwa organisasi berkembang melalui fungsi-fungsi yang semakin beragam, mulai dari tahap fungsi dasar technical core ditambah dengan aktivitas-aktivitas pendukung 
(support activities), tugas - tugas pemeliharaan (maintenance tasks), ditambah dengan fungsi adaptasi (adaptive function)". Proses ini menyebabkan terjadinya diferensiasi horizontal.

Diferensiasi horizontal melahirkan spesialisasi dan departementasi. Spesialisasi merujuk pada pengelompokan aktivitas tertentu yang dilakukan seorang individu dalam organisasi. Bentuk spesialisasi terdiri atas spesialisasi fungsional dan spesialisasi sosial. Pengertian departementasi merujuk kepada pengelompokan berdasarkan spesialisasi-spesialisasi yang ada dalam organisasi, baik spesialisasi fungsional maupun sosial. Hal yang menjadi perhatian dalam kopleksitas suatu organisasi, apakah berada pada posisi tinggi atau rendah kompleksitas tersebut. Tinggi rendahnya kompleksitas terlebih jika tinggi akan menghadapi konsekuensi terhadap perlunya kegiatan dari unsur pimpinan terhadap mekanisme control, komunikasi dan koordinasi. Tiga indikator dari dimensi kompleksitas ini (mekanisme kontrol, komunikasi dan koordinasi) menjadi pengukuran penting penelitian ini.

Komponen kedua dari struktur organisasi adalah formalisasi. (Robbins, 1994, hlm. 103) mengatakan bahwa: "formalisasi merujuk pada tingkat sejauhmana pekerjaan di dalam organisasi distandarisasikan". Tegasnya menurut (Robbins, 1994): “formalisasi adalah pekerjaan yang distandarisakan.Standarisasi dalam pekerjaan sangat penting untuk menghindari keanekaragama dalam pekerjaan dan berfungsi sebagai pengaturan perilaku dalam kerja".

Komponen ketiga dari struktur organisasi adalah sentralisasi. Sentralisasi menurut Robbins (dalam Kusdi, 2009, hlm. 173): " he degree to which the formal authority to make discretionary choises is concentrated is an individual, unit, or level (usually high in the organization), thus permiiting employees( usually low in the organization) minimum input to their work". Intinya dimaksud dengan sentralisasi menyangkut sejauhmana otoritas formal untuk membat pilihan-pilihan bebas apakah terkonsentrasi pada seseorang, unit, atau suatu level (biasanya berposisi tinggi dalam organisasi) sehingga pegawai yang berada pada posisi rendah hanya dimungkinkan memberikan input seminimal mungkin dalam pekerjaan. Sentralisasi menggambar posisi pusat pengambilan keputusan.

Apa yang diartikan tentang keefektifan organisasi itu sendiri, (Robbins, 1994, hlm. 85) memberikan suatu definisi: "sebagai tingkatan pencapaian organisasi atas tujuan jangka pendek (tujuan) dan jangka panjang (cara). Pemilihan itu mencerminkan konstituensi strategis, minat pengevaluasi, dan tingkat kehidupan organisasi". Nampak sekali penarikan definisi keefektifan organisasi menurut pandangan Robbin dibangun dari empat perspektif keefektifan organisasi sebagaimana telah dijelaskan secara singkat tersebut di atas.

Dari berbagai macam teori dan pemikiran diatas, ditarik bentuk kerangka pemikiran dari penelitian seperti pada Gambar 2.1 berikut : 


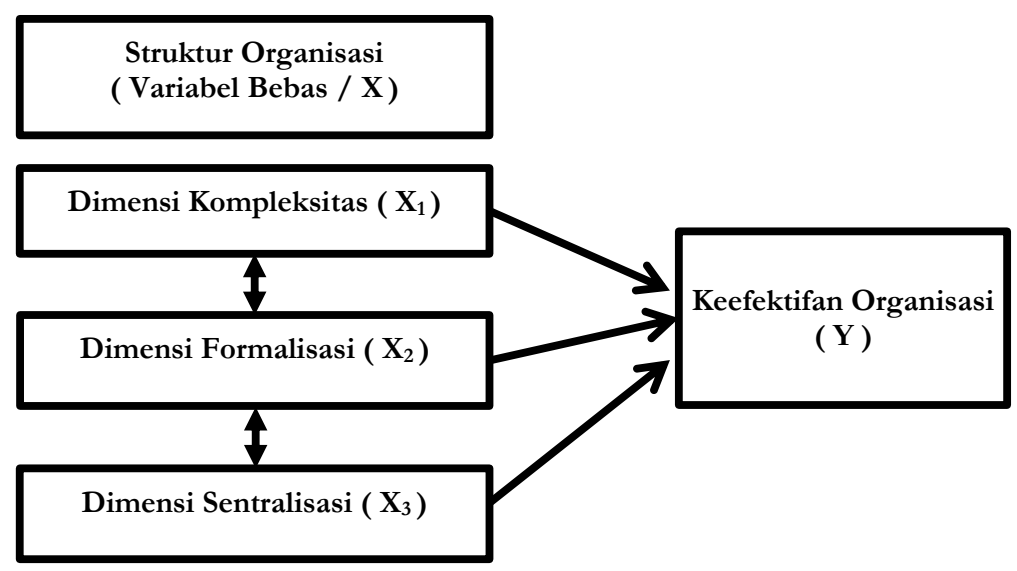

\section{Gambar 1.1 Kerangka Pemikiran Penelitian \\ Sumber : (Robbins, 1994, hlm. 103-105)}

\section{B. Metode (Method)}

Metode penelitian yang digunakan dalam penelitian ini adalah metode penelitian survei. Menurut (Singarimbun \& Effendi, 2006, hlm. 25), Ciri khas penelitian adalah data dikumpulkan dari responden dengan menggunakan kuisioner. Variabel independent dalam penelitian ini adalah struktur organisasi dan variabel dependent dalam penelitian ini adalah keefektifan organisasi.

Populasi dalam penelitian ini adalah jumlah keseluruhan karyawan Pegawai Negeri Sipil (PNS) di lingkungan SETDA Kabupaten Tasikmalaya sebanyak 193 PNS. Teknik pengambilan sampel yang digunakan dalam penelitian ini adalah probability sampling melalui Proportionate Stratified Random Sampling dan didapat sampel penelitian sebanyak 66 responden

Penulis menyebarkan angket. Angket tersebut kemudian dimasukkan ke dalam tabel distribusi frekuensi relative dan skor. Kemudian hasilnya direkapitulasi dan dihitung berdasarkan perhitungan yang telah ditentukan. Maka dapat dilihat hasil dari variabel bebas maupun variabel terikat dengan kriteria sangat rendah, rendah, sedang, tinggi dan sangat tinggi. Penulis menggunakan teknik analisis data yaitu menghitung koefisien korelasi, menghitung factor residu, menghitung analisis jalur (path analysis) dan Pengujian Hipotesis. Kemudian dimasukan ke dalam rumus statistik dengan mengunakan software SPSS.

\section{Temuan Hasil Penelitian (Research Finding)}

Berdasarkan hasil penelitian, pengaruh Struktur Organisasi terhadap Keefektifan Organisasi di Sekretariat Kabupaten Tasikmalaya menunjukan nilai koefisien korelasi sebesar $r=0,842$ dimana angka ini menunjukan bahwa Struktur Organisasi $(X)$ mempunyai hubungan kuat terhadap Keefektifan Organisasi di Sekretariat Daerah Kabupaten Tasikmalaya. 
Tabel 1.1 Model Summary

\begin{tabular}{|l|r|r|r|r|}
\hline Model & \multicolumn{1}{|c|}{$\mathrm{R}$} & R Square & $\begin{array}{c}\text { Adjusted R } \\
\text { Square }\end{array}$ & $\begin{array}{c}\text { Std. Error of } \\
\text { the Estimate }\end{array}$ \\
\hline 1 & $.842^{\mathrm{a}}$ & .708 & .694 & 5.88670 \\
\hline
\end{tabular}

Sumber: Hasil Penelitian Tahun 2019

a. Predictors: (Constant), X3, X2, X1

Koefisien Determinasi ( $R$ Square) menunjukan $R=(0,842)^{2}=0,708$ dengan demikian dapat dikatakan bahwa Struktur Organisasi $(X)$ mempengaruhi Keefektifan Organisasi (Y) sebesar 0,708 yang artinya sebesar 70,8 \%. Keefektifan Organisasi di Sekretariat Daerah Kabupaten Tasikmalaya dipengaruhi oleh Struktur Organisasi (X) dan sisanya sebesar 29,2\% dipengaruhi oleh variabel lainnya yang tidak diteliti oleh penulis, misalnya adanya motivasi, kepemimpinan, manajemen kinerja dan lain sebagainya.

\section{Diskusi (Discussion)}

Analisis pengolahan data statistik ini menggunakan tingkat kepercayaan 95\% sehingga jika terjadi kesalahan maksimum hanya 5\%. Menggunakan Analisis Jalur (path analysis) untuk Pengaruh Struktur Organisasi terhadap Keefektivan Organisasi Di Sekretariat Daerah Kabupaten Tasikmalaya, yang terdiri dari 3 dimensi yaitu Kompleksitas (X1), formalisasi (X2), Sentralisasi (X3) terhadap Keefektifan Organisasi (Y).

Pengujian Hipotesis Secara simultan antara Stuktur Organisasi terhadap Keefektifan Organisasi .

Ho : Tidak ada pengaruh signifikan antara Stuktur Organisas $(X)$ terhadap Keefektifan Organisasi (Y)

Ha : Terdapat pengaruh antara Stuktur Organisasi $(X)$ terhadap Keefektifan Organisasi (Y) Tingkat Signifikansi menggunakan 0,05 ( $\mathrm{a}=5 \%)$ dengan kriteria pengujian :

Dikarenakan F hitung 50,962 > 8,58; maka tolak H0 berarti terima Ha yang artinya Terdapat pengaruh secara simultan antara Stuktur Organisasi $(X)$ terhadap Keefektifan Organisasi (Y). Struktur organisasi yang di Setda Kabupaten Tasikmalaya, dimana dari 3 (tiga) dimensi Kompleksitas, Formalisasi dan Sentralisasi secara simultan memiliki pengaruh yang signifikan terhadap Keefektifan Organisasi. Peran dan Fungsi Pimpinan di organisasi SETDA Kabupaten Tasikmalaya dari mulai Sekretaris Daerah, Asisten Daerah, para Kepala Bagian dalam memberikan perintah, komando, arahan sudah berjalan dengan baik, dan secara keseluruhan sudah dapat diimplementasikan oleh para pegawainya di tingkat bawah. 
Uji hipotesis secara parsial adalah sebagai berikut :

- Pengujian pengaruh Dimensi Kompleksitas (X1) terhadap Keefektifan Organisasi (Y) diperoleh nilai probabilitas sebesar 0,225 karena nilai probabilitas lebih besar dari 0,05 maka dapat diartikan bahwa Dimensi Kompleksitas (X1) berpengaruh positif tetapi tidak signifikan terhadap Keefektifan Organisasi (Y).

- Pengujian pengaruh Dimensi Formalisasi (X2), terhadap Keefektifan Organisasi (Y) diperoleh nilai probabilitas sebesar 0,357 karena nilai probabilitas lebih besar dari 0,05 maka dapat diartikan Dimensi Formalisasi (X2) berpengaruh positif tetapi tidak signifikan terhadap Keefektifan Organisasi $(\mathrm{Y})$.

- Pengujian pengaruh Dimensi Sentralisasi (X3), terhadap Keefektifan Organisasi (Y). diperoleh nilai probabilitas sebesar 0,357 karena nilai probabilitas lebih besar dari 0,05 maka dapat diartikan bahwa Dimensi Sentralisasi (X3) berpengaruh positif tetapi tidak signifikan terhadap Keefektifan Organisasi (Y).

\section{E. Kesimpulan (Conclusion)}

Berdasarkan hasil penelitian dan pembahasan dapat disimpulkan sebagai berikut:

1. Struktur Organisasi berkorelasi positif terhadap Keefektifan Organisasi di Sekretariat Daerah Kabupaten Tasikmalaya dengan nilai korelasi $(\mathrm{r})=0,842$ dan besarnya koefisien determinan $(\mathrm{R})=0,708$ yang artinya Keefektifan Organisasi dapat dijelaskan oleh Struktur Organisasi sebesar 70,8 \%..

2. Hasil analisis data diperoleh F hitung 50,962 > F tabel 8,58, maka tolak H0 yang berarti terima Ha yang artinya secara simultan Terdapat Pengaruh yang positif dan signifikan antara Stuktur Organisasi $(X)$ terhadap Keefektifan Organisasi (Y).

3. Struktur organisasi yang di Sekretariat Daerah Kabupaten Tasikmalaya, dari 3 dimensi Kompleksitas, Formalisasi dan Sentralisasi secara simultan memiliki pengaruh yang signifikan terhadap Keefektifan Organisasi. Peran dan Fungsi Pimpinan di organisasi SETDA Kabupaten Tasikmalaya dari mulai Sekretaris Daerah, Asisten Daerah, para Kepala Bagian dalam memberikan perintah, tugas komando, arahan sudah berjalan dengan baik, dan secara keseluruhan sudah dapat dilaksanakan oleh para pegawainya di tingkat bawah.

4. Secara parsial, Kompleksitas X1, Formalisasi X2, Sentralisasi X3) berpengaruh positif tetapi tidak signifikan terhadap Keefektifan Organisasi (Y) di Setda Kabupaten Tasikmalaya. 


\section{Referensi}

Gibson, James L. 1996. Organisasi: Perilaku, Struktur, Proses. ed. Ninuk Andriani. Jakarta: Binarupa Aksara.

Keban, T. Yeremias. 2014. Enam Dimensi Startegis Administrasi Publik, Konsep, Teori Dan Isu. Yogyakarta: Gavamedia.

Kusdi. 2009. Teori Organisasi Dan Administrasi. Jakarta: Salemba Humanika.

Robbins, Stephen P. 1994. Teori Organisasi: Struktur, Desain Dan Aplikasi. ed. Jusuf Udaya. Jakarta: Arcan.

Singarimbun, Masri, and Sofian Effendi. 2006. Metode Penelitian Survei. Jakarta: LP3ES.

Sugiyono. 2010. Metode Penelitian Pendidikan Pendekatan Kuantitatif, Kualitatif dan RED. Bandung: Alfabeta. 